DOI: $10.12731 / 2658-4034-2020-2-39-44$

\title{
МЕЖЛИЧНОСТНЫЕ ОТНОШЕНИЯ МЛАДШИХ ШКОЛЬНИКОВ, ЗАНИМАЮЩИХСЯ ТАНЦЕВАЛЬНЫМ СПОРТОМ
}

\author{
Босенко Ю.М., Распопова А.C.
}

Кубанский государственный университет физической культуры, спорта и туризма, г. Краснодар, Российская Федерация

В статье описаны результаты диагностики особенностей межличностных отношений и изучения представлений о себе младиих школьников $(n=77)$, занимающихся $(n=40)$ и не занимающихся $(n=37)$ таниевальным спортом.

Ключевые слова: младший школьник; межличностные отношения; спортивные танцы.

\section{INTERPERSONAL RELATIONSHIPS OF YOUNGER STUDENTS INVOLVED IN DANCE SPORTS}

\author{
Bosenko Yu.M., Raspopova A.S.
}

Kuban state University of physical culture, sports and tourism, Krasnodar, Russian Federation

The article describes the results of diagnostics of the features of interpersonal relations and the study of self-image of younger students $(n=77)$ who are engaged in $(n=40)$ and not engaged in $(n=37)$ dance sports.

Keywords: Junior high school student; interpersonal relationships; sports dancing.

Спортивные танцы являются одним из средств формирования физической и эстетической культуры личности. Стоит отметить стремительный рост числа юных спортсменов, включённых в этот вид деятельности [1, с. 289]. Актуальной проблемой в связи с этим становится анализ условий, в которых происходит развитие лич- 
ностного потенциала юного спортсмена, в частности, структура межличностных взаимоотношений, которая проявляется в процессе спортивной деятельности [2, с. 138]. Известно, что межличностные отношения в процессе занятий спортом влияют на личностное развитие юных спортсменов, обогащая опыт взаимодействия. Это позволяет развивать психическое благополучие юного спортсмена, занимающегося танцевальным спортом [3, с. 548].

Несмотря на то, что имеется ряд исследований о психологических особенностях занимающихся танцевальным спортом, имеется дефицит данных о спортсменах младшего школьного возраста. Недостаточно данных об особенностях становления межличностных отношений у юных спортсменов в данном виде спорта. Именно это противоречие и определило актуальность нашего исследования.

Цель - определить особенности межличностного общения младших школьников, занимающихся танцами. Задачи: выявить особенности взаимоотношений внутри коллектива младших школьников, занимающихся и не занимающихся танцами; изучить особенности межличностных отношений, поведения и представлений о себе младших школьников, занимающихся и не занимающихся танцами.

Методы исследования: метод социометрии (параметрический вариант); опросник В.Стефансона (Q-сортировка); методика «Межличностные отношения» Р.Жиля; метод математической статистики (t-критерий Стьюдента).

Сравнение средних значений, полученных при определении социометрического статуса, свидетельствуют о том, что младшие школьники в целом имеют близкие показатели статуса в группе. Индекс эмоциональной экспансивности в группе занимающихся составил 0,35, а в группе не занимающихся 0,22, что свидетельствует о стремлении детей к общению, желании постоянно взаимодействовать с другими, иметь большой круг знакомств. Мы видим, что среднее значение в группе детей младшего школьного возраста, не занимающихся танцами несколько ниже, чем в группе посещающих танцевальные занятия. У детей, занимающихся танцами стремление к общению может быть выше за счет достаточно большого количества внешних связей. Индекс психологической взаимности в груп- 
пе занимающихся составил 0,81 , а в группе не занимающихся 0,36 , обнаружены достоверные различия. Младшие школьники в группе занятий танцами имеют более высокий индекс сплоченности группы. На специальных занятиях у младших школьников могут создаваться более близкие, доверительные отношения со сверстниками. Это может объясняться спецификой самих занятий.

Социальный статус детей не соответствует их эмоциональной экспансивности (потребности в общении), что говорит о том, что дети не удовлетворяют в группе свою потребность в общении и нуждаются в более широких связях и контактах.

Уровень благополучия взаимоотношений (УБВ) в обеих группах может быть охарактеризован как благополучный: сумма «звезд» и «предпочитаемых» больше, чем «принятых» и «изолированных» членов группы. Однако это соотношение очевидно гораздо выше в группе занимающихся (25\%), чем не занимающихся (10\%) что свидетельствует о более высоком уровне благополучных взаимоотношений в ней. Общий процент «предпочитаемых» и «лидеров» в группе детей, занимающихся танцами несколько выше, чем в группе не занимающихся.

В результате диагностики по методике «Межличностные отношения ребенка» Р. Жиля выявлено, что практически все диагностируемые поведенческие характеристики имеют среднее значение. Испытуемые имеют нормальный уровень развития межличностного общения. Сравнивая средние значения в двух группах, занимающиеся танцами, оказываются ближе к матери, чем к другим родственникам, и имеют чуть более высокие значения в общительности в группе и близости к педагогу. Не занимающиеся танцами более любознательны и одинаково близки к обоим родителям. Таким образом, подтверждается большее стремление занимающихся к независимости и самостоятельности. Занимающиеся танцами достоверно чаще, чем не занимающиеся, стремятся доминировать и быть лидерами. Такие данные могут объясняться соревновательным эффектом, который является необходимым компонентом для постоянных занятий танцами. Также достоверно выше у спортсменов показатели агрессивности, конфликтности и отгороженности, что может быть постоянные соревнования приводят к развитию духа конкуренции. 
Показатель «реакции на фрустрацию» достоверно выше у не занимающихся спортом, что может говорить о меньшей социальной адаптации испытуемых, в то время как анимающиеся танцами, более подготовлены к ситуациям неудачи, нацелены на преодоление любых препятствий. Развитая произвольность в поведении и деятельности, значительные волевые усилия, которые закрепляются на систематических занятиях, позволяют им более спокойно относиться к ситуациям, блокирующим удовлетворение потребностей.

Применив методику Q-сортировки, мы проанализировали общие тенденции, характерные для младших школьников, которые свидетельствуют о том, что они больше стремятся к общительности, имеют примерно равные значения в паре зависимость-независимость. Они уже достаточно самостоятельны, хотя привыкли ориентироваться и доверять чужому мнению. Чаще всего такими значимыми лицами для них являются взрослые: родители, учитель, зависимость от мнения которых очень велика в это время. Такие результаты подтверждают основные особенности развития межличностных отношений в этом возрасте. Склонность же к «принятию борьбы» может быть объяснена особенностями выборки: половину испытуемых составили дети, занимающиеся танцами, и имеющие достаточно высокий показатель по этой шкале. Не занимающихся танцами скорее склонны к зависимости и общительности.

Самое низкое значение имеет шкала необщительности, что говорит об открытости и желании иметь большое количество друзей и знакомых. Занимающиеся танцами имеют тенденцию к общительности, склонны к независимости и ориентированы на «принятие борьбы», чем на ее избегание.

У младших школьников, занимающихся танцами достоверно выше тенденция к независимости и «принятию борьбы». Такие результаты говорят о том, что дети, посещающие танцевальные занятия, оказываются более самостоятельными и устойчивыми к трудностям. Это может объясняться особенностью деятельности, которой они занимаются помимо учебной. Разнообразные публичные выступления вырабатывают устойчивость к внешним воздействиям, а соревновательная атмосфера развивает боевой настрой. 
Многочисленные исследования в сфере ранней профессионализации подтверждают выявленную тенденцию к раннему взрослению и личностному развитию детей, занимающихся танцевальным спортом [4, с. 26; 5, с. 201]. Занятия танцами создают дополнительные условия для более успешной адаптации ребенка в социуме [6, с. 393]. Ускоренное взросление младшего школьника, занимающегося танцами, может создавать сложности во взаимоотношениях со сверстниками из обычной школы, развивать завышенную самооценку, провоцируя ряд трудностей. В системе дополнительного образования важно психологически грамотно учитывать результаты исследования особенности развития межличностных отношений младших школьников для создания благоприятной атмосферы в танцевальной группе, а также с целью учета индивидуальных особенностей детей.

Таким образом, проведенное исследование показало, что танцевальные занятия создают условия для более удачной социальной адаптации ребенка в социуме, через развитие межличностных отношений ребенка с коллективом, сверстниками и взрослыми.

Информация о конфликте интересов. Отсутствие конфликта интересов.

Информация о спонсорстве. Исследование не имело спонсорской поддержки.

\section{Список литературы}

1. Вакуленко Е.С. Танцевальный спорт как одно из направлений современного спорта // Тезисы докладов XLVI научной конференции студентов и молодых ученых вузов Южного федерального округа Материалы конференции. 2019. С. 298.

2. Пархоменко Е.А., Дубовова А.А., Прицюк О.Е. Особенности психологической готовности юных спортсменов к занятиям спортивными и бальными танцами // Физическая культура и спорт. олимпийское образование Материалы международной научно-практической конференции. 2019. С. 138-140.

3. Харитонова И.В., Берилова Е.И., Белоконь В.О., Фокина И.С. Эмоциональный интеллект как основа личностной готовности к профес- 
сиональной самореализации спортсменов разной квалификации // Ученые записки университета им. П.Ф. Лесгафта. 2019. № 11 (177). C. $548-552$.

4. Давыдов М.В., Зиновьев А.Н., Купреев М.В., Ивачев А.А. Физическая культура. Танцевальный спорт. Методическое пособие / СанктПетербург, 2019. 28 с.

5. Распопова А.С., Босенко Ю.М., Харитонова И.В. Психология физической культуры и спорта. Учебное пособие / Краснодар, 2019. 260 с.

6. Серова Л.К., Чернышева Л.Г., Сидоров Е.И. Психологическая характеристика танцевального спорта // Ученые записки университета им. П.Ф. Лесгафта. 2019. № 1 (167). С. 393-397.

\section{Referenses}

1. Vakulenko E.S. Tanceval'nyj sport kak odno iz napravlenij sovremennogo sporta // Tezisy dokladov XLVI nauchnoj konferencii studentov i molodyh uchenyh vuzov Juzhnogo federal'nogo okruga Materialy konferencii. 2019. S. 298.

2. Parhomenko E.A., Dubovova A.A., Pricjuk O.E. Osobennosti psihologicheskoj gotovnosti junyh sportsmenov k zanjatijam sportivnymi i bal'nymi tancami // Fizicheskaja kul'tura i sport. olimpijskoe obrazovanie Materialy mezhdunarodnoj nauchno-prakticheskoj konferencii. 2019. S. 138-140.

3. Haritonova I.V., Berilova E.I., Belokon' V.O., Fokina I.S. Jemocional'nyj intellekt kak osnova lichnostnoj gotovnosti k professional'noj samorealizacii sportsmenov raznoj kvalifikacii // Uchenye zapiski universiteta im. P.F. Lesgafta. 2019. № 11 (177). S. 548-552.

4. Davydov M.V., Zinov'ev A.N., Kupreev M.V., Ivachev A.A. Fizicheskaja kul'tura. Tanceval'nyj sport. Metodicheskoe posobie / Sankt-Peterburg, 2019. $28 \mathrm{~s}$.

5. Raspopova A.S., Bosenko Ju.M., Haritonova I.V. Psihologija fizicheskoj kul'tury i sporta. Uchebnoe posobie / Krasnodar, 2019. $260 \mathrm{~s}$.

6. Serova L.K., Chernysheva L.G., Sidorov E.I. Psihologicheskaja harakteristika tanceval'nogo sporta // Uchenye zapiski universiteta im. P.F. Lesgafta. 2019. № 1 (167). S. 393-397. 